\title{
A Struggle for Domination - A Role of the Carpathian German Party in Nazification of the German Community in Slovakia Milan OLEJNÍK
}

\begin{abstract}
Two decades of existence of the First Czechoslovak Republic (CSR) were a time of adaptation of its citizens to the flow of changes, which affected all aspects of political, economic and social life. As a consequence of democratic political system, inhabitants of Czechoslovakia could actively participate in political activities in the Republic. Shortly after establishment of CSR, a number of political parties were founded, including associations representing ethnic minorities. In Slovakia, the most numerous minority was the Hungarian one and next to it the German minority. Similarly like the Slovak majority, also these ethnic groups were represented by several political parties, which associated themselves either with a coalition of ruling parties, or stayed in opposition. The paper analyzes the political development of German minority parties in Slovakia during the existence of the inter-war CSR. The attention is focused upon the differences of political orientation of two major German settlements in Slovakia - the Germans living in Bratislava and its surroundings and German community in the region of Spiš. Whereas the Carpathian German Party, which held a dominant position in Bratislava since its inception at the close of twenties, aspired to be a sole representative of German minority in Slovakia, the Spiš German Party was the most influential in the region of Spiš. Despite being a political representative of overwhelming majority of German minority members in Spiš, it pursued a pro-Hungarian policy and closely cooperated with Hungarian opposition parties. The Spiš German Party refused any form of cooperation with the Carpathian German Party, which during the second half of thirties became a part of the Sudeten German Party and took an active role in spreading of Nazi ideology in Slovakia.
\end{abstract}

\section{Keywords}

German minority, Hungarian minority, Nazification

A demise of the Austro-Hungarian Empire ushered a dramatic change of geopolitical situation in the region of the Central Europe. Foundation of new states led to an emergence of radically different political, economic and social conditions which impacted every aspect of life of populations living in newly established state formations. One of the most 
significant phenomena was an emergence of minorities, which became an integral part of ethnic composition of new states.

A sizeable segment of non-Slavic communities formed also ethnic structure of Czechoslovak Republic (CSR). The communities of Germans living in Czechland and to lesser extent also in Slovakia were the most numerous. Though Germans constituted less than $5 \%$ of the population of Slovakia, ${ }^{1}$ they had a share in Slovak complex ethnic composition. Slovak Germans have not been living in one region, but as a result of disparity of German migratory waves, German settlement of Slovakia concentrated predominantly in three regions - in Bratislava and its environs, in the Central Slovakia (a territory known as a Hauerland) and in the region of Spiš. ${ }^{2}$

Differing confessional adherence and different regions of Germany from where German migrants originated, enhanced diversity of German minority in Slovakia. ${ }^{3}$ The diversity of individual segments of German minority resulted in their strong regional attachment and closeness. This was characteristic namely for the Spiš Germans, who maintained practically no contacts with other German enclaves in Slovakia.

Establishment of The Czechoslovak Republic brought a number of opportunities to German minority members in Slovakia but also exposed them to changes which they did not welcome.

A rapid transformation of a geopolitical situation took the German population in Bratislava by surprise. Even though the sentiments of a majority of Germans living in Bratislava toward a new state were ambiguous, pragmatic attitude prevailed.

According to the Czechoslovak Constitution, which was adopted on 29 February 1920, citizens of CSR had right to create political associations formed on ideological, confessional and ethnic base. Consequently, as in the whole Czechoslovakia, a vigorous political activity ensued also in two German enclaves - in Bratislava and in the Spiš region. In Bratislava the German community during the first years after foundation of CSR underwent a rather confusing period of political development. Political subject - the Working Association of German Parties in Slovakia (Arbeitsgemeinschaft der Deutschen Parteien in der Slowakei), which had an aspiration to be a representative of all German minority members, was not able to attract German voters and became extinct. ${ }^{4}$

Political development of German minority members living in Bratislava and its surrounding was influenced by the Sudeten based German political association - the Union of German Farmers (Bund der Landwirte), who expressed as its political goal to work for all Germans, regardless where they lived. An illustrative example was a pronouncement of one of the deputies for the Union of German farmers in the National Assembly, who during the public gathering at Bratislava on 22 May 1922 declared: "It is not our issue to debate if we will be

\footnotetext{
1 According to the census of population realized in 1910, there were 147,501 members of German minority living in Slovakia, that is $4.53 \%$ of the total population. See: Census in Republic of Czechoslovakia from 1 December 1930, in: Československá statistika, vol. 98, Prague 1934.

2 Names of localities are written in Slovak language.

3 The first significant wave of German immigrants into the Hungarian Kingdom occurred in the second half of $13^{\text {th }}$ Century as a result of invitation of King Béla IV. The religious wars, which raged in $16^{\text {th }}$ and $17^{\text {th }}$ Centuries in Europe, led to a migration of Germans into Hungary in search of greater religious freedom. German immigrants flowing into Hungary during $18^{\text {th }}$ Century were motivated by economic opportunities created by industrialization.

4 KOVÁČ, Dušan: Nemecko a nemecká menšina na Slovensku (1871-1945), Bratislava 1991, 71-72.
} 
annexed to Germany, Austria, Poland and back again by Hungary. Our endeavor and duty is to elevate local Germans economically and culturally". ${ }^{5}$

It took almost ten years till a political subject, which gained a dominant influence in community of German minority members, emerged in Bratislava. At the outset of 1928 a German organization named the Carpathian Association (Karpathendeutsche Volkgemeinschaft) was transformed into the Carpathian German Party - CGP (Karpathendeutsche Partei). Also CGP found itself under influence of Sudeten Germans. Franz Karmasin, a Sudeten German from Olomouc, who came in Slovakia in 1926, became an influential activist and was nominated to post of chairman of CGP.

Since its inception, the Carpathian German Party aspired to integrate into its ranks Germans from the whole Slovakia. Territorially CGP was divided into region of Bratislava with surroundings, Nitrianske Pravno - Kremnica and region of Spiš. ${ }^{6}$

Germans living in Spiš, in comparison to Germans living in rest of Slovakia, differed in several significant aspects. Unlike German population in Bratislava, which was predominantly Catholic, Germans of Spiš adhered mostly to the Protestantism. Spiš, especially a lower part of the region, was rich with natural resources, which enabled development of metal working industries. Besides agriculture, it was especially export of metal products to the Hungarian market, which became a foundation of Spiš economy. Assimilative policies of Hungarian government, which intensified after year 1867, were much more successful in Spiš than in Bratislava. There were several significant reasons for it. Economically, the region was almost completely dependent on the Hungarian market. Trade was facilitated by a network of roads which were oriented in north-south direction and built with an aim to connect northern parts of Hungary with Budapest. Adoption of so called "industrialization laws" by Hungarian government during the latter part of the $19^{\text {th }}$ century, designed to protect domestic industry, helped also enterprises producing metal wares, to export their products to the Hungarian market. German community, too small to aspire to any form of autonomy, was not viewing policy of Hungarian government aimed at formation of linguistically and ideologically homogenous state as inimical to their status, on the contrary, they perceived it as an opportunity to participate on political and social life of the Hungarian Kingdom. Even a language, one of the most relevant ethno-identification factors, played only a limited role. A majority of Germans living in Spiš was tri-lingual, that is, the Germans could besides German language communicate also in Hungarian and Slovak languages. The language proficiency of Spiš Germans had roots in ethnic composition of the region. According to census from 1910 there were 97,077 Slovaks, 38,434 Germans and 18,658 Hungarians living in Spiš. ${ }^{7}$

One of the most efficient vehicles of assimilative policies of the Hungarian Government was education. For illustration, whereas in school year 1904/1905 fifty-seven elementary schools with German teaching language existed in Slovakia, in school year 1912/1913 only nineteen schools with German teaching langue remained. Higher education was completely

5 Slovenský národný archív (Slovak National Archive in Bratislava, hereinafter referred only as SNA), fund Policajné riaditel'stvo (Police Directory hereinafter referred to only as PR), carton 251, doc. No. 251/410.

6 SNA, f. PR, carton 251, doc. No. 251/782.

7 TAJTÁK, Ladislav: Spiš a vznik Československa, in: Spiš v kontinuite času, ŠVORC, Peter (ed.), Prešov - Bratislava - Wien 1995, 145. 
hungarized. ${ }^{8}$ Even though many members of German intelligentsia were getting their education at universities in Germany, they kept their adherence to the "Hungarian State Idea". A German activist Edmund Steinacker who tried, unsuccessfully, to elevate German national awareness, ruefully admitted that Spiš Germans were in reality "fiery Hungarian patriots". "Therefore, inclusion of the Spiš region into the Czechoslovak Republic was for a majority of Spiš Germans unwelcome geopolitical change.

After collapse of the Austro-Hungarian Empire, the National Council of Spiš County was established. Representatives of this political association declared that inhabitants of the region of Spiš are wishing to remain in the Hungarian Kingdom. ${ }^{10}$ Similarly, representation of the Upper Hungarian Peoples Council of Germans (Oberungarischer Volksrat der Deutschtum) protested against inclusion of Spiš to Czechoslovakia and declared that even the Slovak population of Spiš wanted to belong to Hungary. ${ }^{11}$ Another, rather desperate measure to keep Spiš in an orbit of Hungary was declaration of so called the Independent Spiš Republic (Selbständige Zipser Republik) in Kežmarok on 9 December 1918. ${ }^{12}$ However, these initiatives intended to prevent an inclusion of Spiš into CSR were futile. A week later the Czechoslovak Army entered into Poprad.

Unlike political development of the German political scene in Bratislava, in the Spiš region a position of dominance was held, since its foundation in 1920, by the Spiš German Party - SGP (Zipserdeutsche Partei). Since 1922, a chairman of the SGP was Andor Nitsch, a landowner from Tatranská Lomnica. The Spiš German Party maintained a close cooperation with two main Hungarian opposition parties - the Provincial Christian Social Party - PChSP (Országos Kereszténnyszocialista Párt) and the Hungarian National Party - HNP (Magyar Nemzeti Párt). The pro-Hungarian attitude of the Spiš German Party was reflected also in its political orientation. During its existence, SGP participated on local and parliamentary elections as an ally of above mentioned political associations.

The CGP emphasized in its political program a determination to improve a status of all Germans in Slovakia in economic and cultural sphere.

Aspirations of the Carpathian German Party to become a political leader of all Germans in Slovakia and its cooperation with political parties representing German minority in Czech part of the Republic ${ }^{13}$ were contrary to pro-Hungarian political orientation of the Spiš German Party.

Contrary to the Carpathian German Party, which pursued a policy of cooperation with German political subjects, and emphasized that all German communities in Slovakia must unite, ${ }^{14}$ SGP refused this proposition arguing that this policy is detrimental to Germans living in Spiš because it will result in destruction of their historical roots and their culture.

8 POTEMRA, Michal: Školstvo na Slovensku v rokoch 1901-1918, Košice 1993, 341-347.

9 KOVÁČ, 20.

10 TAJTÁK, 149.

11 Ibidem, 150-151.

12 Ibidem, 152.

13 The Union of Farmers (Bund der Landwirte) and the German Working and Economic Association (Deutsche Arbeits und Wirtschaftsgemeninschaft).

14 After elections in 1929, CGP concluded an alliance with the Union of Farmers and the German Working and Economic Association. 
Exponents of CGP, who were active in region of Spiš, ${ }^{15}$ were branded as epigones of Sudeten Germans who want deprive the Spiš Germans of their heritage. ${ }^{16}$

On elections of 1929 the Spiš German party participated in coalition of PChSP and HNP. The coalition obtained 257,231 votes and chairman of SGP A. Nitsch got a seat in the House of Representatives. ${ }^{17}$

However, unshakable pro-Hungarian orientation of a majority of Spiš Germans was jeopardized. There were two major factors which had an impact upon situation of German minority members living in Spiš. First was a radical change-over of educational system after establishment of the Czechoslovak Republic. Besides a massive build-up of Slovak schools, also schools for German community were built. This was in line with Article 9 of Saint-Germain Agreement signed by Czechoslovak representatives. Obligation stated in Saint-Germain Agreement was translated into Czechoslovak legislative as Zásady jazykového práva (the Principles of Language Law) adopted by the National Assembly on 29 February $1920 .{ }^{18}$ In all regions inhabited by German minority members, including region of Spiš, schools with German teaching language were built. In school year 1920/1920, there were in operation 102 elementary schools with German teaching language, with total attendance of 13,784 pupils. ${ }^{19}$ However, not only education in German langue but also a content of education underwent a radical change. As contrary to the Hungarian Kingdom, where the decisive political power was held by the aristocracy, the democratic nature of the Czechoslovak Republic was emphasized. The changes of content were most radical in such subjects like history and literature in which glorification of the Hungarian Kingdom was eliminated from education. As the main threat to Czechoslovak territorial integrity was by members of Czechoslovak government perceived as a policy of revision of the Treaty of Versailles, pursued by Hungary. Therefore, to eliminate pro-Hungarian sentiments of German minority members, which especially in Spiš were deeply rooted, was perceived by Czechoslovak state authorities as desirous. And as the most proper vehicle to achieve this aim it was considered to be schools with the German teaching language. But, as future political development showed, this process had unintended catastrophic consequences. In the second half of thirties, when Nazi ideology was influencing a growing number of German community members, it was also young Spiš Germans who embraced it.

Another important factor was change of status of Slovak Germans in regard to other German enclaves after establishment of the Czechoslovak Republic. German enclaves in Slovakia founded themselves in one state with Sudeten Germans, who came in contact with German communities living in Slovakia, of which they had before only a negligible knowledge. A number of Sudeten Germans were coming to Slovakia, where they were active as teachers and cultural activists. They also actively participated on formation of

15 For example, K. Manoušek, an entrepreneur of Sudeten German extraction, who was one of the representatives of the Carpathian German Party in Spiš.

16 Štátny archív Levoča (State Archive Levoča, hereinafter referred only as SAL, branch Spišská Nová Ves, hereinafter referred only as branch SNV), fund Okresný úrad (County Office, hereinafter referred only as CO) Gelnica, carton 42, without number.

17 Elections to National Assembly in October 1929, in: Československá statistika, vol. 70, Prague 1930, chart No. 1, p. 7.

18 Sbírka zákonů a nařízení státu československého 1920, Častka 25, 6. března 1920, zákon č. 122 [Journal of Laws and Orders of the State of Czechoslovakia 1920, 25. 6 March 1920, Act No. 122]

19 SNA Bratislava, f. A. Štefánek, carton 14, without number. 
sport associations and became instrumental in spreading of Pan-German ideology with all its negative consequences. These circumstances also facilitated growing influence of the Carpathian German Party in Spiš.

At the beginning of year 1930, CGP published a memorandum criticizing policy of leaders of the Spiš German Party who allegedly were betraying Spiš Germans by pursuing interests of Hungary in time when wellbeing of German population in Slovakia could be achieved only via united political representation. In reaction, SGP published two memoranda in which accused the Carpathian German Party of pursuing aims of Nazi Germany to the detriment of Slovak Germans and emphasized contributions which the Spiš German Party provided in sphere of economy and culture for German population in Spiš. ${ }^{20}$ It was clear that there will be no possibility to conciliate political stands pursued by both parties.

As was already noted, the Spiš German Party was an ally of Hungarian opposition parties and actively supported their endeavors to achieve autonomy of Slovakia. During the conference held on September 1931 by Hungarian opposition parties in Žilina, A. Nitsch pledged support of SGP to political goals of Hungarian opposition.

The imposition of the Nazi regime in Germany in 1933 had a deep impact upon situation in the whole Central Europe including the Czechoslovak Republic. In a relatively short time after coming to power German dictator Adolf Hitler changed Germany into a totalitarian state, which became a direct threat to neighboring countries, especially to Austria and Czechoslovakia. A. Hitler openly stated that his aim was to annex all regions inhabited by Germans to Germany, even if that will mean violating sovereignty of states in which Germans lived. Czechoslovak authorities reacted by adopting a number of legislative measures intended to enhance security of state and allowed government agencies to implement more stringent approach against opposition political parties. ${ }^{21}$

Czechoslovak authorities dissolved two German political parties - the German National Party (Deutschenational Partei) and the German National Socialist Workers Party (Deutschenationalsozialistische Arbeiterpartei) which were classified as extremists. Immediately before prohibition, the German Nationalistic Workers Party was voluntarily dissolved. Shortly after, the Sudeten Patriotic Front - SPF, was established, which, before parliamentary elections in 1935, was renamed to the Sudeten German Party - SuGP.

Nazification of Germany influenced political development of German community in Czechoslovakia. Authority of chairman of SuGP Konrad Henlein grew among Sudeten Germans. The Sudeten German Party also gained adherents in Slovakia. CGP established close ties with SuGP and before elections to the National Assembly in 1935 concluded an alliance with SuGP. The alliance of CGP and SuGP was during pre-election campaign explained by activists of the Carpathian German Party as a measure necessary to improve the status of all Germans in Slovakia. ${ }^{22}$

Political influence of CGP grew also in community of Spiš Germans. Pro-Hungarian

20 KOVÁČ, 79.

21 For example on 10 July 1933, the Law No. 124 was adopted, which novelized the Law No. 50 "For protection of the Republic" from year 1923; the Law No. 125 "In regard to extraordinary measures" was adopted; on 24 December 1934 the Law No. 269 was adopted, which novelized the Law No. 201, regulating abolition of political parties.

22 SNA, f. PR, carton 245, doc. No. 245/380. 
orientation of SGP was criticized as a failure of its leadership to reflect changing situation and necessity to work for unification of all Germans. Activists of the Carpathian German Party emphasized during public gatherings that SGP wasted last fifteen years and was incapable to improve status of Germans living in Spiš. ${ }^{23}$

Leadership of CGP was aware how important an ally the Sudeten German Party is. Therefore, shortly before elections to the National Assembly, CGP joined the Sudeten German Party. According to a secret clause of the agreement, the Carpathian German Party received financial help to cover expenses associated with an election campaign and F. Karmasin was guaranteed a seat in the National Assembly. ${ }^{24}$ As a change of name documented, CGP entered election campaign as an integral part of the Sudeten German Party. Its official name was altered to the Carpathian German Party - Chairman Konrad Henlein. In its situational report, elaborated before elections, the Police Directory Košice estimated that as consequence of growing popularity of the Carpathian German party, the Spiš German Party will lose a considerable number of votes. ${ }^{25}$ Usually well informed Police Directory Košice judged situation correctly. A. Nitsch could retain his mandate in the National Assembly only because he was placed on list of candidates of the Hungarian National Party. On the contrary, in comparison with elections held in 1929, CGP obtained in 1935 almost twice as many votes. ${ }^{26}$ CGP was gaining votes also in the region of Spiš. ${ }^{27}$ With an aim to increase its influence in Slovakia, representatives of the Sudeten German Party intensified contacts with CGP and made frequent trips to all regions inhabited by German minority members. These were monitored by Czechoslovak authorities. The Provincial Office, ${ }^{28}$ instructed district offices in Slovakia to report on each visit of Sudeten German emissaries and made reports about relevant events which occurred during these visits. ${ }^{29}$ One form of influencing of Slovak Germans, namely members of young generation, was organizing trips to Germany. According to the Provincial Office, which instructed subordinated government authorities to monitor these trips, the German organization Kraft durch Freude was helping to finance excursions of young German minority members to Germany. These trips allegedly had "purely propagandistic goal, to influence visitors by ideas of the National Socialism and made them spread Nazi ideology after their return to Slovakia". 30

Sport activities were traditionally popular among young German minority members. An important place among the German sport associations in Slovakia held the German Sport

23 SAL, b. SNV, f. CO Gelnica, carton 119, without number.

24 KOVÁČ, 98.

25 Police Directory Košice wrote in its report that "in present elections a position of Nitsch is considerably weakened because in Košice election district also Henlein will candidate, who...can deprive SGP at least about half of votes". Národní archiv (National Archive in Prague, hereinafter referred only as NA), fund Předsednictvo ministerské rady (Bureau of the Ministerial Council, hereinafter referred only as PMR), carton 218.

26 Elections to the National Assembly in May 1935, in: Československá statistika, vol. 134, Prague 1936.

27 Elections to the National Assembly were held in two separate terms - to the Chambers of Deputies on 19 May and to the Senate on 26 May.

28 The Provincial Office was the highest administrative government agency in Slovakia subordinated to the Ministry of Interior in Prague.

$29 \mathrm{SAL}$, b. SNV, f. CO Gelnica, carton 50, without number.

$30 \mathrm{SAL}$, b. SNV, f. CO Gelnica, carton 50, without number. 
Association (Deutscher Turnverband). This, initially non-political organization, during the second half of thirties was accentuating German patriotism and duty of each German to work for unification of Germans in Slovakia. What was more dangerous, Deutscher Turnverband implemented into sport activities elements of military training. ${ }^{31}$

The majority of older generation of Spiš Germans, however, was impervious to the nationalistic propaganda spreading by emissaries and activists of the Carpathian German party. For example, according to report made by government representative, during the public gathering organized by the Carpathian Party in Vrbové, "the speaker did not arouse a deeper interest in crowd of listeners". 32

Even though leadership of the Carpathian German Party was officially declaring loyalty to Czechoslovak Republic, increase of its radicalization was evident.

The more aggressive attitude of SuGP/CGP was a result of external factors. During the second half of thirties Germany undertake a number of steps which were in a direct violation of the Versailles Peace Treaty. By October 1934, size of the German Army was increased from a hundred thousand to three hundred thousand. On 16 March 1935 universal military service was established. Despite that this measure of German government was a violation of the Versailles Treaty, France and Great Britain did not interfered. And then, on 7 March 1936 the German Army occupied the Rhineland. It was extremely audacious step on part of Hitler and German forces were ordered to retreat if French Army attacked. France did nothing. This convinced Hitler that the Western Powers have no will power to stop him and emboldened him to continue his aggressive policy.

The Nazi Germany was able to pursue ruthlessly its goals without any consequences. Therefore, also leaders of the Carpathian German Party took a more aggressive approach toward Czechoslovak government, as well as to German minority members who refused to join its ranks. According to the Provincial Office, activists of the Carpathian German Party criticized sharply minority policy of Czechoslovak government during the public gatherings. Provincial Office instructed government authorities to monitor speeches of exponents of CGP and in cases when speakers would attack political system of the Republic or policies of government, they should dissolve public meeting. ${ }^{33}$ Inflammatory speeches of representatives of the Carpathian German Party, which led to interferences undertaken by state authorities, were criticized by speakers. During the public speech in Švedlár on 12 March 1937 a member of the Senate for CGP condemned restrictive measures of state authorities and said that such incidents will be recorded and written record of it will be submitted to Geneve and London as a proof of suppression of German community by Czechoslovak government. ${ }^{34}$

Besides increased activities of the Carpathian German Party in Spiš, which were aimed at weakening the Spiš German Party, a position of SGP was threatened also by goal of Carpathian German party to establish close ties with Hungarian opposition parties. The stumbling block, however, was their relationship to SGP. Nevertheless, Hungarian opposition

31 BOBRíK, Miroslav: Nemecké telovýchovné organizácie a spolky na Slovensku v rokoch 1929-1938, in: Historický časopis, 41, 1993, 1, 640-674.

32 SAL, f. Štátne zastupitel'stvo (Procurature, hereinafter referred to only as ŠZ), carton NST 12/1936.

33 SAL, f. CO Levoča, carton 40, without number.

34 SAL, b. SNV, f. CO Gelnica, carton 52, without number. 
politicians ${ }^{35}$ who were aware of growing political influence of the Sudeten German Party, decided to cooperate with the SuGP and therefore also with the Carpathian German Party. Chairman of the United Hungarian Party János Esterházy concluded with representatives of SuGP Karl. H. Frank and Gustav Peters an agreement bounding both political subjects to coordinate their policy. A. Nitsch criticized agreement, arguing that it will lead to further weakening of the Spiš German Party. ${ }^{36}$

Despite criticism of A. Nitsch, process of deepening ties between the Sudeten German Party and the United Hungarian Party progressed. Géza Szüllo, one of the foremost leaders of UHP and K. Henlein discussed a strategy of cooperation during the Congress of European minorities in London on $14-15$ July 1937. ${ }^{37}$

Worsening political situation in the Central Europe, in combination with increasing dissatisfaction of representatives of ethnic minorities, convinced Czechoslovak government that is necessary to be more forthcoming to their demands. On 18 February 1937 the Board of Ministers issued a decree Spravedlivá menšinová politika (the Equitable Minority Policy) in which declared that "in an endeavor to contribute to a mutual understanding in ethnic relations in the Republic government will pursue a policy of improving status of ethnic minorities in sphere of economic, education, language right and will implement measures to increase employment of members of ethnic minorities in state agencies." ${ }^{38}$ The Provincial Office in Bratislava ordered subordinated government agencies in Slovakia to unconditionally follow instructions stated in the cited decree and to make sure that language rights of minorities will be maintained in an official conduct. ${ }^{39}$

The principle of equitable employment of ethnic minorities in government agencies was confirmed by the Chamber of deputies during its session on 4 December 1937 which remained government offices that a principle of proportional employment of minorities must be observed with "utmost precision" ${ }^{40}$ On 3 February 1938 the Provincial Office instructed district offices in Slovakia to carry an official conduct in localities where minority members live in sufficient numbers stated by law in languages of these minorities. All measures of Czechoslovak government implemented with an aim to ease tense relations with representatives of ethnic minorities, were dependent on stabilization of political situation in the Central Europe and belligerent policy of Germany offered only small hope that this will happen.

On 20 February 1938, A. Hitler delivered in Reichstag a speech in which he openly declared that Germany will not tolerate that ten million Germans live in states neighboring Germany in condition of subjugation. It was clear that neighboring states were Austria and Czechoslovakia. Less than a month later Hitler proved that his speech was not only empty threat.

In early hours of 12 March 1938 the German Army entered territory of Austria. There was

35 The Provincial Christian Party and the Hungarian National Party united into one political subject - the United Hungarian Party (UHP), during the congress in Nové Zámky on 21 June 1936.

36 NA, f. BCM, carton 575, doc. No. 206/35.

37 KOVÁČ, 113.

38 The decree was published on 2 February 1937.

39 SAL, f. CO Levoča, carton 47, without number.

40 SNA, f. PR Bratislava, carton 223, doc. No. 223/510. 
no resistance and on 14 March 1938 A. Hitler triumphantly entered Vienna. Again, even though France and Great Britain protested, both countries abstained from any meaningful reaction against Germany. It became clear that German dictator can commit an act of aggression against sovereign state without any consequences.

Czechoslovak government despite worsening security situation of the Republic, tried to play down a negative impact of annexation of Austria by Germany. For a majority of German minority and especially for leadership of the SuGP/CGP this was proof that Germany is a decisive power broker in the Central Europe. German aggression had a disastrous impact upon German minority parties who till then resisted to subordinate themselves to the Sudeten German Party. On 23 March 1938 German Agrarians - Bund der Landwirte, with explanation that policy of Czechoslovak government did not improve status of German minority, joined the Sudeten German Party. Two days later German Christian Socialists joined SuGP. Only German Social Democrats and the German Democratic Liberal Party (Deutsche Democratische Freiheitpartei) refused to join SuGP.

Changes in German political scene in Czechoslovakia further increased political influence of the Carpathian German Party. A. Nitsch steadfastly refused to accept any form of cooperation with CGP. Representatives of the United Hungarian Party, who were keen to build friendly relations with the Carpathian German party, criticized A. Nitsch for his inflexible attitude. In his negative stance to CGP, Nitsch found an ally in K. Förster, a leader of the German Christian Socialists in Bratislava. According to K. Förster political orientation of both parties will remain "hungarofill and anti-Henlein". ${ }^{41}$ This agreement, however, was rather an episode which could not in any significant measure stop growing influence of SuGP/CGP in Slovakia. On the contrary, K. Henlein, emboldened by his latest success, during the congress of the Sudeten German Party in Karlovy Vary on 25 April 1938 declared demands of which fulfilment by Czechoslovak government would be necessary to solve conflict between CSR and Sudeten Germans. At the end of his speech, Henlein pronounced that a fundamental principle of ideology of SuGP is the National Socialism "to which all Germans in the world are today adhering". ${ }^{42}$ These were scandalous requirements, which would end Czechoslovakia as unitary state and compromise security of the Republic to such extend that would be unable to resist the German attack. Demands raised by Henlein were unison refused by representatives of Czechoslovak government. Despite a clear violation of law, government authorities did not intervened against Henlein.

In Slovakia the Carpathian German Party abandoned its previous proclamations of loyalty to the Republic and initiated more aggressive propaganda. The CGP also stepped up its attacks upon the Spiš German Party. Spiš Germans, who were still loyal to the SGP, were accused of betrayal of German community and derisively termed as "living anachronisms" ${ }^{43}$ Also Hungarian minority opposition parties were criticized for their support given to SGP. ${ }^{44}$

41 NA, f. PMR, carton 575, without number.

42 LAFFAN, R. D. G.: Survey of international affairs 1938. Volume II. The Crisis of Czechoslovakia January to September 1938, London - New York - Toronto 1951, 96.

$43 \mathrm{SAL}$, f. ŠZ, carton Nst III. 27/28.

44 During public gathering in Bratislava, chairman of parliamentary club of SuGP/CGP Ernst Kund declared that it is inconceivable why Hungarian opposition parties are supporting the Spiš German party. They should realize that only united Hungarians and united Germans could successfully fight for their rights. SNA, f. PR Bratislava, 
Hungarian opposition leaders were trying to prevent conflict with the Carpathian German Party. According to information of the Police Directory in Bratislava, Andor Jaross, the chairman of UHP instructed Hungarian opposition periodicals to prevent publishing of any articles hostile to the Carpathian German Party in particular and to the Nazi Germany in general.

For A. Jaross friendly relations with Germans were so important that he even agreed to terminate any support to A. Nitsch and K. Förster and also agreed that all CGP take over all German organizations which were till then included in the United Hungarian Party. Both parties also agreed to pursue same political strategy and inform each other about decisions which will be taken. The agreement between CGP and UHP was a heavy blow to already weakened SGP German Party. However, Hungarian government still maintained hope that the Spiš German Party could be saved. Unlike Hungarian opposition leaders in Slovakia who perceived cooperation with SuGP/CGP as instrumental to their goals in Slovakia, members of Hungarian government, especially regent Miklós Horthy, Prime Minister Béla Imrédy and Minister of Foreign Affairs Kálmán Kánya were not inclined to unconditional support of Germany and were rather afraid of Hitler. During the visit of Hungarian delegation in Germany, Horthy allegedly refused Hitler's suggestions that Hungary will join Germany in attack upon Czechoslovakia with excuse that Hungarian Army is not well armed. He even declined Hitler's offer to assist in rearming of Hungarian military. ${ }^{45}$ Similarly Imrédy and Kánya refused overtures of German Foreign Minister Joachin von Ribentropp to gain their promise to join an aggression against CSR. Therefore, during the summer months A. Nitsch could still count on support of Hungarian government.

However, more important than support from Hungary was political development in Spiš. SGP was constantly losing its membership base. Meantime SuGP/CGP were openly displaying their pro-Nazi orientation. Provocations against CSR abounded. Nazi ideology penetrated into all strata of German community. For example in Bratislava even school children were infatuated by Nazi euphoria. According to report of Czechoslovak army headquarters in Bratislava dispatched on 14 May 1938 to the Police Directory, inscriptions "Heil Hitler!" were occurring on school buildings in growing numbers.

In worsening political situation the possibility that an agreement between Czechoslovak government and representatives of ethnic minorities will be reached, was negligible. During the meeting of Prime Minister Hodža with leaders of the United Hungarian Party on 29 June 1938 M. Hodža promised that the National Statue will guarantee same status for all ethnic communities. The United Hungarian Party obtained the National Statute in July 1938. However, following example of SUGP/CGP, which was adamantly against any agreement with Czechoslovak Government, also UHP refused to accept it. The refusal was explained that the National Statute did not contain provisions in regard to establishment of self-governments which was demanded by UHP. ${ }^{46}$

In the middle of May 1938, representatives of the Sudeten German Party terminated negotiations with Czechoslovak government. In regions bordering with Germany tense

carton 248, doc. No. 248/714.

45 HORTHY, Nicholas: Memoirs, New York 1957, 162.

46 SIMON, Attila: The Hungarians of Slovakia in 1938, New York 2012, 5. 
situation resulted in occasional acts of violence. Situation, however, stabilized after on 20 May when a partial mobilization of reservist was declared. Even though mobilization, which was enacted without consultation with France and Great Britain and was criticized by governments of both states, proved that Czechoslovakia is determined to defend its borders, it was no permanent solution. However, this resolute measure toned down radical speeches of exponents of SuGP/CGP. At the public gathering of the Carpathian German Party in Gelnica, F. Karmasin denied accusations that CGG is hostile to Czechoslovakia and is trying to subvert government. ${ }^{47}$

During the summer months of 1938 activists of the Carpathian German Party intensified their campaign in Spiš against the Spiš German Party. They appealed to all members of German minority to join CGP warning that those who will refuse will face consequences after Germany will occupy CSR. The Provincial Office reacted to this form of campaigning by issuing on 22 August 1938 a circular instructing all government agencies in Slovakia to prohibit all incidents which would violate Czechoslovak law, "namely use of threats, which would disturb public peace". ${ }^{48}$

But assertion of authority of state was only short lived. Besides, the situation of the Spiš German Party was hopeless. With exception of hard core stalwarts, mostly members of older generation, for whom the Nazi ideology was repulsive, an overwhelming majority of Germans in Spiš embraced nationalistic euphoria and became members of the Carpathian German Party.

The escalation of tensions in Sudeten region, which erupted after Hitler's speech on 12 September 1938, led to dissolution of the Sudeten German Party and its branch the Carpathian German Party by Czechoslovak authorities. These resolute measures, however, were nullified after the Munich Agreement. In Slovakia, the strongest Slovak opposition party - Hlinka's Slovak People Party succeeded in established Slovak autonomy and assumed a role of political dominance. These changes resulted in a renewal of political activity of former CGP. F. Karmasin exploited enormous increase of influence of Germany and informed Slovak autonomous government that on 10 October 1938 he founded the German Party as a legal successor to dissolved CGP. Minister F. Durčansky readily granted permission and the German Party was legalized on 12 October 1938. The triumphant German Party became the sole political representative of the German minority in Slovakia. In its ten years lasting existence, the Carpathian German Party underwent a dramatic transformation, which was in a decisive measure influenced by external factors. Even though since its inception, the Carpathian German Party had ambition to be a political representative of all Germans living in Slovakia, it did not act as a radical nationalistic organization. Leaders of CGP repeatedly declared their loyalty to the Republic and focused their political activities upon improvement of status of German minority members. This changed in the second half of thirties as a direct consequence of Nazification of Germany. The adherence of the Carpathian German Party to Nazi ideology caused radicalization of a majority of ethnic Germans in Slovakia. Only the Spiš German Party, which was the most influential political subject among German population of Spiš region, steadfastly refused

47 SAL, b. SNV, f. CO Gelnica, carton 142, without number.

48 SAL, b. SNV, f. CO Gelnica, carton 60, without number. 
Nazism and its exponents. However, regardless how determined leadership of SGP was in its refusal of Nazi ideology and its representative the Carpathian German Party it was powerless to stop it. After the Munich Agreement, the Nazification of Germans in Slovakia was almost complete.

\section{References}

Národní archiv (National Archive in Prague, NA), fund Předsednictvo ministerské rady (Presidium of the Council of Ministers, PMR), CBM

Slovenský národný archív (Slovak National Archive in Bratislava, SNA) fund Policajné riaditel'stvo (Police Directory, PR); fund A. Štefánek

Štátny archív Levoča (State Archive Levoča, SAL), fund Štátne zastupitel'stvo (Procurature, ŠZ)

Štátny archív Levoča, pobočka Spišská Nová Ves (State Archive Levoča, branch Spišská Nová Ves, SAL, b. SNV), fund Okresný úrad (County Office, CO) Gelnica; fund Okresný úrad (County Office, CO) Levoča

Sbírka zákonů a nařízení státu československého 1920, Částka 25, 6. března 1920, zákon č. 122 [Journal of Laws and Orders of the State of Czechoslovakia 1920, 25. 6 March 1920, Act No. 122].

BOBRÍK, Miroslav: Nemecké telovýchovné organizácie a spolky na Slovensku v rokoch 1929 - 1938, in: Historický časopis, 41, 1993, 1, 640-674.

HORTHY, Nicholas: Memoirs, New York 1957.

KOVÁČ, Dušan: Nemecko a nemecká menšina na Slovensku (1871-1945), Bratislava 1991.

LAFFAN, R. D. G.: Survey of international affairs 1938. Volume II. The Crisis of Czechoslovakia January to September 1938, London - New York - Toronto 1951.

POTEMRA, Michal: Školstvo na Slovensku v rokoch 1901-1918, Košice 1993.

Census in Republic of Czechoslovakia from 1 December 1930, in: Československá statistika, vol. 98, Prague 1934.

SIMON, Attila: The Hungarians of Slovakia in 1938, New York 2012.

TAJTÁK, Ladislav: Spiš a vznik Československa, in: Spiš v kontinuite času, ŠVORC, Peter (ed.), Prešov - Bratislava - Wien 1995, 145-153.

Elections to the National Assembly in October 1929, in: Československá statistika, vol. 70, Prague 1930.

Elections to the National Assembly in May 1935, in: Československá statistika, vol. 134, Prague 1936.

\section{Author}

doc. Mgr. Milan Olejník, PhD.

Spoločenskovedný ústav Košice, Slovenská akadémia vied

Institute of Social Sciences in Košice, Slovak Academy of Sciences

Kurská 23, Košice 04022, The Slovak Republic

olejnik@saske.sk 